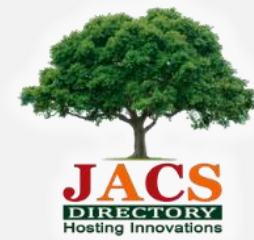

Journal of Nanoscience and Technology

\title{
Aloe vera (L.) Assisted Green Synthesis and Structural and Optical Studies of $\mathrm{Y}_{2} \mathrm{O}_{3}: \mathrm{Mg}^{2+}$ Nanocomposite
}

\author{
Hajeebaba K. Inamdar ${ }^{1}$, Chelana R. Jain ${ }^{1}$, Rajesh Siddanna², M.V.N. Ambika Prasad1,* \\ ${ }^{1}$ Department of PG Studies and Research in Physics, Gulbarga University, Gulbarga - 585 105, Karnataka, India. \\ ${ }^{2}$ Department of Physics, Reshmi UG \& PG College, Kalaburgi - 585 106, Karnataka, India.
}

\section{ART ICLE DETAILS}

\section{Article history:}

Received 20 April 2018

Accepted 02 May 2018

Available online 21 May 2018

\section{Keywords:}

$\mathrm{Y}_{2} \mathrm{O}_{3}: \mathrm{Mg}^{2+}$

PXRD

Aloe vera

\begin{abstract}
A B S T R A C T
For the first time green route method was used to synthesize pure and $\mathrm{Mg}^{2+}(1-11 \mathrm{~mol} \%)$ doped $\mathrm{Y}_{2} \mathrm{O}_{3}$ nanophosphors by using Aloe vera leaves extract as a fuel. The final product was well characterized by powder X-ray diffraction (PXRD), scanning electron microscopy (SEM), transmission electron microscopy (TEM) and diffuse reflectance spectroscopy (DRS). The PXRD pattern reveal that the formation of single phase, cubic structure of $\mathrm{Y}_{2} \mathrm{O}_{3}$ with crystallite sizes $\sim 25 \mathrm{~nm}$. The SEM results showed porous and agglomerated structures. TEM images showed the crystallite size of the material and were found to be around $\sim 25 \mathrm{~nm}$. DRS studies revealed that the band gap of the nanophosphors was found to be around 5.82 to $5.87 \mathrm{eV}$.
\end{abstract}

\section{Introduction}

Yttrium oxide $\left(\mathrm{Y}_{2} \mathrm{O}_{3}\right)$ received important attention in the latest years in view of its possible integration into a wide range of scientific and technological applications such as luminescent displays, photoelectric devices, optoelectronics devices, biological, chemical probes etc., [1, 2]. Nanostructured $\mathrm{Y}_{2} \mathrm{O}_{3}$ shows outstanding physical properties such as wide energy band gap $(\sim 5.30 \mathrm{eV})$, high dielectric constant, optically isotropic and refractive index of about 1.91 [3-5]. Rare earth doped $\mathrm{Y}_{2} \mathrm{O}_{3}$ was alert to be the best phosphors for practical applications because of their superb luminescent efficiency, color purity, chemical and thermal stability [4] they discover variety of applications like display devices, up-conversion solar cells, white-light generation and detectors in medical diagnosis equipment etc., [5]. The development of a simple, environmental responsive method to practice $\mathrm{Mg}^{2+}$ doped $\mathrm{Y}_{2} \mathrm{O}_{3}$ nanostructures with controllable morphology was necessary to their practical applications [611]. The facile bio-combustion method using Aloe vera plant extract as a fuel/surfactant offers a facile mode for low rate and large-scale assembly. Aloe vera plant known as sensitive plant scattered throughout in India in moist locality [1]. Present work focus on the synthesis of series of $\mathrm{Mg}^{2+}(1-$ $11 \mathrm{~mol} \%$ ) doped $\mathrm{Y}_{2} \mathrm{O}_{3} \mathrm{NPs}$ with different morphologies prepared via bio approach.

\section{Experimental Methods}

The raw materials, used in the present study were yttrium nitrate

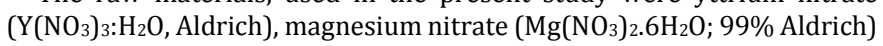
as a sources of $\mathrm{Y}$ and $\mathrm{Mg}$ respectively. Aloe vera (L.) leaf extract gel was used as a fuel/surfactant. The method of extracting the Aloe vera leaf extract was discussed elsewhere [6]. The structural characterization of the sample was performed using Powder X-ray diffractometer (Shimadzu 7000). The structural morphological properties and particle size of nanocomposites were observed by scanning electron microscopy (Table top SEM, Hitachi - TM-3000), transmission electron microscopy (TEM, JEOL JSM 2100) using Horiba Flurolog Spectrofluorimeter at room temperature.

\subsection{Synthesis $\mathrm{Y}_{2} \mathrm{O}_{3}: \mathrm{Mg}^{2+} \mathrm{NCS}$}

The extract of Aloe vera gel was mixed thoroughly in equal ratios of double distilled water using a magnetic stirrer. For the synthesis of $\mathrm{Y}_{2} \mathrm{O}_{3}$ : $\mathrm{Mg}^{2+}(5 \mathrm{~mol} \%)$ aqueous mixtures of yttrium nitrate and magnesium nitrate solutions were subsequently added to the required amount of Aloe vera gel of $(10 \mathrm{~mL})$. Then it was introduced into the muffle furnace preheated at $450 \pm 5^{\circ} \mathrm{C}$. The obtained product was grinded well to get fine powder.

\section{Results and Discussion}

\subsection{PXRD Analysis}

Fig. 1 shows the powder diffraction pattern (PXRD) patterns of $\mathrm{Y}_{2} \mathrm{O}_{3}$ : $\mathrm{Mg}^{2+}$ (1-11 mol\%) NPs prepared via Aleo vera plant mediated green combustion route.

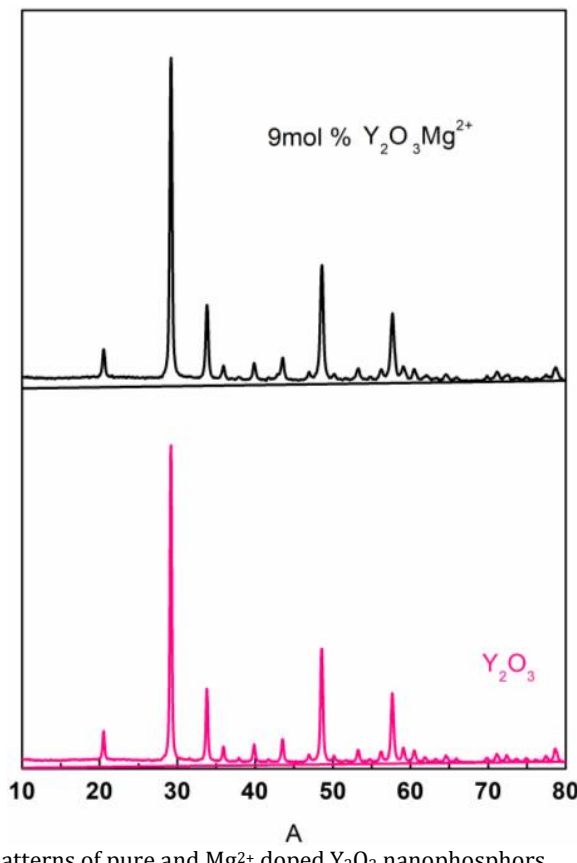

Fig. 1 PXRD patterns of pure and $\mathrm{Mg}^{2+}$ doped $\mathrm{Y}_{2} \mathrm{O}_{3}$ nanophosphors 
The PXRD pattern was well indexed to cubic $\mathrm{Y}_{2} \mathrm{O}_{3}$ with JCPDS No. 881040. The crystallite size (D) of $\mathrm{Y}_{2} \mathrm{O}_{3}: \mathrm{Mg}^{2+} \mathrm{NPs}$ were estimated using Scherer's equation. The host matrix effects of strain and crystallite size was probable by Williamson-Hall $(\mathrm{W}-\mathrm{H})$ plots. The crystallite size estimated from Scherer's equation and $\mathrm{W}-\mathrm{H}$ plots was found to be in the range $\sim 25 \mathrm{~nm}$. A small difference was observed in the estimated crystallite size determined from Scherer's equation [1]. The variation in the size was due to the fact that in Scherer's equation the strain component was presumed to be zero.

\subsection{Morphological Studies}

Fig. 2 shows the SEM micrographs of $\mathrm{Y}_{2} \mathrm{O}_{3}: \mathrm{Mg}^{2+}$ (9 mol\%) nanophosphors. The NPs were seen with spread dumb-bell shaped like structure, which were due to Aleo vera fuel effect. The chemical constituents present in the fuel acts as capping agent which binds the NPs to form different structures.

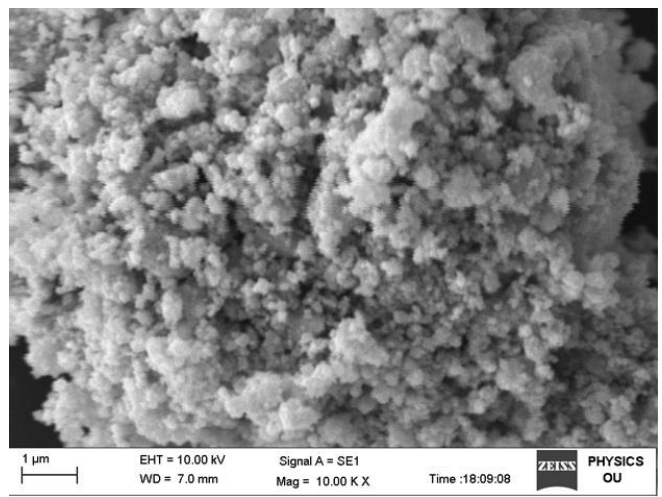

Fig. 2 SEM micrographs of $\mathrm{Y}_{2} \mathrm{O}_{3}: \mathrm{Mg}^{2+}(9 \mathrm{~mol} \%)$ nanophosphor

\subsection{TEM Analysis}

To provide further evidence in the formation of nanostructures with different morphologies TEM, HRTEM were carried out and were as shown in Fig. 3. The TEM images shows the agglomerated NPs consisting large number of cubic flakes. The crystallite size of the NPs was found to be 25 $\mathrm{nm}$ which was in good agreement with the crystallite sizes estimated by Scherer's equation and W-H plot method.

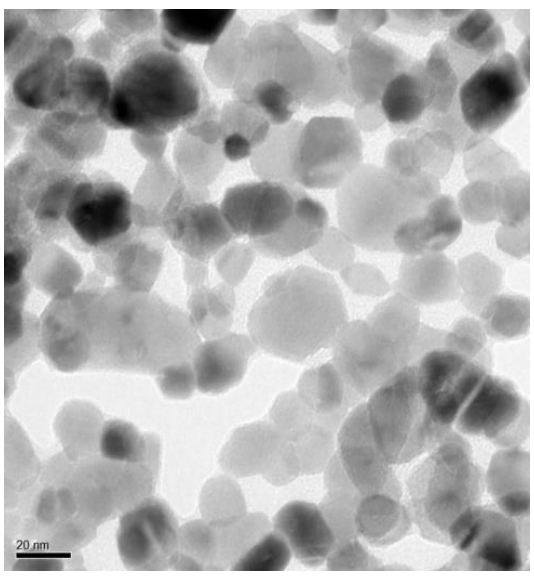

Fig. 3 TEM of $\mathrm{Y}_{2} \mathrm{O}_{3}: \mathrm{Mg}^{2+}(9 \mathrm{~mol} \%)$ nanophosphors

All these outcome combining with PXRD analysis further confirm that $\mathrm{Mg}^{2+}+$ ions have been successfully caped into the $\mathrm{Y}_{2} \mathrm{O}_{3}$. The follow-on product was calcined at $650^{\circ} \mathrm{C}$ for $2 \mathrm{~h}$ for better crystalinity.

\subsection{Spectroscopic Studies}

Optical energy gap (Eg) of $\mathrm{Y}_{2} \mathrm{O}_{3}: \mathrm{Mg}^{2+}(1-11 \mathrm{~mol} \%)$ NPs prepared through combustion technique was estimated using Tauc relation elsewhere [1] and the obtained values were found to be in the range 5.87$5.92 \mathrm{eV}$ (Figs. 4 and 5).

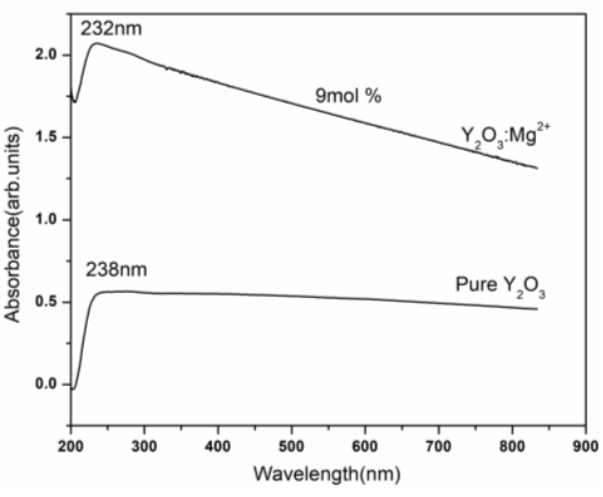

Fig. 4 Absorbance spectra of pure and $\mathrm{Y}_{2} \mathrm{O}_{3}: \mathrm{Mg}^{2+}(9 \mathrm{~mol} \%)$ nanophosphors

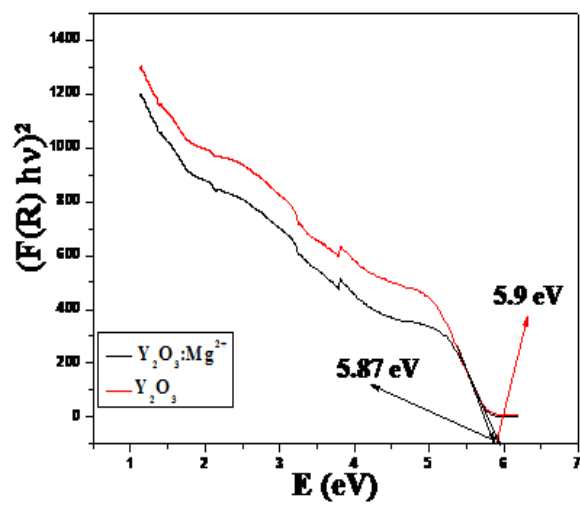

Fig. 5 Energy band gap plots of pure and $\mathrm{Y}_{2} \mathrm{O}_{3}: \mathrm{Mg}^{2+}(9 \mathrm{~mol} \%)$ nanophosphors

\section{Conclusion}

For the first point in time cubic $\mathrm{Y}_{2} \mathrm{O}_{3}: \mathrm{Mg}^{2+}$ (1-9 mol\%) NPs were synthesized by a superficial, ecofriendly, cheap, bio-inspired solution combustion method using Aloe vera leaves extract as a fuel. The structural, optical, morphology properties were well supported to the scope of this work. Also the present nanophosphor can serve as a potential candidate for optical devices.

\section{References}

[1] C.S. Goh, J. Wei, L.C. Lee , M. Gupta, Properties and deformation behaviour of $\mathrm{Mg}-\mathrm{Y}_{2} \mathrm{O}_{3}$ nanocomposites, Acta Mater. 55 (2007) 5115-5121.

[2] Y. Doi, M. Haneda, M. Ozawa, Direct decomposition of NO on Ba catalysts supported on rare earth oxides, Jour. Mol. Catal. A Chem. 383-384 (2014) 7076.

[3] Z. Shenglin, Study on phosphating treatment of aluminum alloy: role of yttrium oxide, Jour. Rare Earths 27(3) (2009) 469-475.

[4] S.M. Choi, H.L. Lee, Formation of the fluorite phase and other related phases in the system $\mathrm{Y}_{2} \mathrm{O}_{3} \pm \mathrm{Ta}_{2} \mathrm{O}_{5} \pm \mathrm{MO}\left(\mathrm{M}_{5} \mathrm{Mg}\right.$, Ca, Sr or Ba), Jour. Mater. Sci. 33 (1998) 2577-2582.

[5] Z.L.Q. Wang, Y. Yang, C. Tao, H. Yang, Luminescent properties of codoping $\mathrm{Y}_{2} \mathrm{O}_{3}$ : $\mathrm{Eu}, \mathrm{Me}\left(\mathrm{Me}_{5} \mathrm{Mg}, \mathrm{Ca}\right)$ nanorods, J. Nanopart. Res. 12 (2010) 2233-2240.

[6] C.S. Chen, C.C. Chou, Rietveld refinement on $\mathrm{BaTiO}_{3}$ materials doped with $\mathrm{MgO} / \mathrm{Y}_{2} \mathrm{O}_{3}$ additives, Ferroelect. 355 (22007) 159-164.

[7] Y. Kondo, T. Ejima, K. Saito, T. Hatano, M. Watanabe, High-reflection multilayer for wavelength range of 200-30 nm, Nuclear Instru. Method. Phys. Res. A 467468 (2001) 333-336

[8] S.M. Ambalgi, H.K. Inamdar, V.T. Manjula, S.G. Sannakki Nagaraja, Synthesis characterization and electrical properties of polyaniline/nickel oxide nanocomposites, Int. J. Eng. Res. 5(2) (2016) 119-122.

[9] R. Siddanna, H.K. Inamdar, A. Mugalgaon, M.V.N. Ambikaprasad, Green synthesis of $\mathrm{ZnO}$ nanoparticles their structural and biological applications, Int. J. Scien. Res. Sci. Eng. Technol. 4(1) (2018) 831-834.

[10] S.M. Ambalagi, H.K. Inamadar, B. Sannakki, Materials mechanism of DC conductivity measurement of zinc oxide doped polyaniline, Nanocomp. Today Proc. 3 (2016) 3945-3950.

[11] S. Farheen, F. Jahan, H.K. Inamdar, R.D. Mathad, Effect of polymer blending on mechanical and thermal properties, Modern Appl. Sci. 12(1) (2015) 520-522. 